\title{
NC22 I 3: a novel methionine aminopeptidase 2 inhibitor in human colon cancer HT29 cells
}

\author{
Ponniah Selvakumar ${ }^{1,2}$, Ashakumary Lakshmikuttyamma ${ }^{2,3}$, \\ Umashankar Das ${ }^{4}$, Hari N Pati ${ }^{4}$, Jonathan R Dimmock ${ }^{4}$ and \\ Rajendra K Sharma*1,2
}

Address: ${ }^{1}$ Department of Pathology and Laboratory Medicine, College of Medicine, University of Saskatchewan, Saskatoon, Saskatchewan, S7N 4H4, Canada, ${ }^{2}$ Cancer Research Unit, Health Research Division, Saskatchewan Cancer Agency, Saskatoon, Saskatchewan, S7N 4H4, Canada, ${ }^{3}$ Department of Biochemistry, College of Medicine, University of Saskatchewan, Saskatoon, Saskatchewan, S7N 4H4, Canada and ${ }^{4}$ College of Pharmacy and Nutrition, University of Saskatchewan, Saskatoon, Saskatchewan, S7N 5C9, Canada

Email: Ponniah Selvakumar - ponniah.selvakumar@saskcancer.ca; Ashakumary Lakshmikuttyamma - ashakum@hotmail.com; Umashankar Das - umd251@usask.ca; Hari N Pati - hari.pati@advinus.com; Jonathan R Dimmock - jr.dimmock@usask.ca; Rajendra K Sharma* - rajendra.sharma@saskcancer.ca

* Corresponding author

Published: 24 August 2009

Molecular Cancer 2009, 8:65 doi:10.1 186/1476-4598-8-65
Received: 19 June 2009

Accepted: 24 August 2009

This article is available from: http://www.molecular-cancer.com/content/8/I/65

(c) 2009 Selvakumar et al; licensee BioMed Central Ltd.

This is an Open Access article distributed under the terms of the Creative Commons Attribution License (http://creativecommons.org/licenses/by/2.0), which permits unrestricted use, distribution, and reproduction in any medium, provided the original work is properly cited.

\begin{abstract}
Methionine aminopeptidase 2 (MetAP2) is a bifunctional protein that plays a critical role in the regulation of post-translational processing and protein synthesis. MetAP2 is overexpressed in human colon cancer. In this report we screened various MetAP2 inhibitors and treated HT29 cells with various concentrations of compounds. We evaluated the expression of MetAP2 and Pp60c-src expressions in HT29 cells. In addition we also carried out the cell proliferation and cell cycle analysis in the MetAP2 inhibitor-treated HT29 cells. The cell cycle analysis of HT29 treated with $1.0 \mu \mathrm{M}$ of $\mathrm{NC22} / 3$ showed an arrest in the $\mathrm{G} 2$ phase followed by an induction in the percentage of cells undergoing apoptosis in the sub-GI phase. Western blot analysis revealed that the MetAP2 expression was dose-dependently decreased when the HT29 cells were treated with the 3,5bis(benzylidene)-4-piperidone derivative (NC22/3). In addition, phosphorylation of Src, a myristoylated oncoprotein was significantly decreased by $1.0 \mu \mathrm{M}$ of $\mathrm{NC22} / 3$ as revealed by Western blot analysis. Furthermore, NC22 13 also inhibits the expression of pp60c-src in HT29 cells. Interestingly, this compound also inhibits the phosphorylation at Tyr416 of pp60c-src while increasing the phosphorylation at Tyr527 of pp60c-src. NC22 I3 inhibits the growth of HT29 cells by inducing apoptosis and might be useful for the treatment of human colon cancer.
\end{abstract}

\section{Findings}

Methionine aminopeptidases (MetAPs) are the enzymes responsible for the removal of methionine from the amino-terminus of newly synthesized proteins $[1,2]$ which is essential for further amino terminal modifications (e.g., myristoylation of glycine by N-myristoyltrans- ferase, NMT) $[3,4]$. Various reports suggested that MetAP2 plays an important role in the growth of different types of tumors [5]. Anti-sense of MetAP2 also induces apoptosis in rat hepatoma cells [6]. A recent study suggested that fumagillin effectively inhibits both liver tumor growth and metastasis in rats in vivo [7]. Higher MetAP2 expres- 
sion was reported in malignant mesothelioma [8], malignant lymphomas [9] and esophageal squamous carcinomas [10]. The angiogenesis inhibitor TNP470, O(chloro-acetyl-carbamoyl) fumagillol, a synthetic analogue of fumagillin, suppressed the expression of MetAP2 in human neuroblastoma and thus, MetAP2 may be an important molecular target for human neuroblastomas [11]. Earlier, we demonstrated the high expression of MetAP2 in colorectal adenocarcinoma patients [12]. It appears that higher expression of MetAP2 is required for the overexpression of NMT in colon carcinogenesis.

The purpose of the present study is to identify a novel MetAP2 inhibitor. We screened various small molecules using a cell proliferation (MTT) assay. Among several compounds screened, we identified 2-\{3-[3,5-bis[4nitrobenzylidene]-4-oxopiperidin-1-yl]-3-oxopropylsulfanyl\} ethanesulfonic acid NC2213 (Figure 1), which is structurally divergent from fumagillin, as an inhibitor of MetAP2. Various cytotoxic evaluations against human squamous cells (HSC-2, HSC-4), and leukemic cells (HL60) displayed moderate inhibition [13]. HT29 colon cancer cells were treated with NC2213 at a concentration range of 0 to $5.0 \mu \mathrm{M}$ for 96 hours to confirm a dosedependent inhibitory effect. NC2213 inhibited HT29 cells, human colon cancer cell lines (HCCL), in a dosedependent manner with an $\mathrm{IC}_{50}$ value of $1.2 \mu \mathrm{M}$ (Figure 2A). HT29 cell proliferation was significantly inhibited by $1.0 \mu \mathrm{M}$ of NC2213. The effects of NC2213 on cell cycle progression and cell death in HT29 cells were analyzed by flow cytometric analysis of the DNA content using fixed, propidium iodide-stained cells. HT29 cells were exposed to NC2213 at various concentrations for 48 hours. The addition of NC2213 $(1.0 \mu \mathrm{M})$ seemed to abrogate the G2$M$ arrest and significantly increased the population of cells with sub-G (apoptotic) DNA content. The percentage of G1 cells decreased 50\% with $1.0 \mu \mathrm{M} \mathrm{NC2213} \mathrm{after} 48$ hours. The cell cycle analysis of HT29 treated with $1.0 \mu \mathrm{M}$ of NC2213 showed an arrest in the G2 phase followed by an induction in the percentage of cells undergoing apoptosis in the sub-G1 phase (Figure 2B).

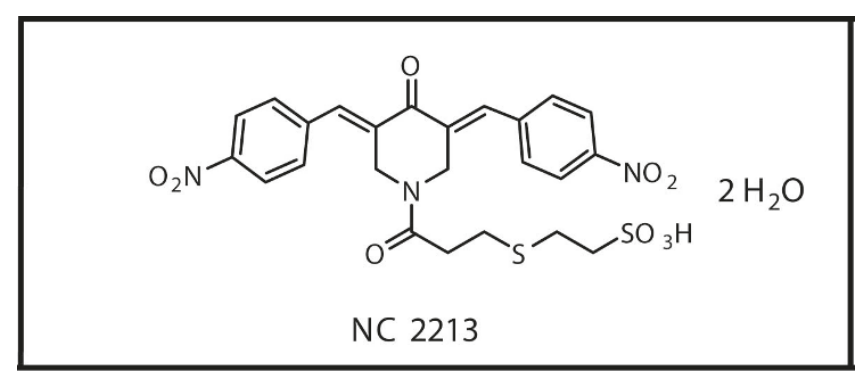

Figure I

Structure of NC22 I 3.
To investigate the inhibition of MetAP2 by NC2213, the dose-dependent effects of NC2213 were evaluated by Western blot analysis. HT29 cells, treated with NC2213 for 48 hours, led to a dramatic decrease in MetAP2 expression (Figure 3A). Very recently, it has been reported that MetAP2 could function as an oncogene [14]. An adenovirus transfer of cMyc increased the expression of MetAP2 in human umbilical vein endothelial cells revealed that cellular proliferation may involve a cross-talk between cMyc and MetAP2. Furthermore, various Src family tyrosine kinases, ADP ribosylation factors and eukaryotic transcription elongation factor-2 were substrates of MetAP2 which plays a significant role in the progression of metastasis [14]. From our above observations it is evident that MetAP2 may serve as a novel target for the treatment of colon cancer. MetAP2 is one such target candidate due to its inactivation by the widely investigated anticancer agent TNP470 [15-17]. A derivative of the natural product fumagillin, TNP470 has been shown to be safe and effective in the treatment of solid tumors in several animal studies and preclinical trials. TNP470 entered human clinical trials for the treatment of AIDS-related Kaposi's sarcoma, metastatic breast cancer, androgen-independent prostate cancer, pediatric solid tumors, lymphomas, acute leukemia, advanced squamous cell cancer of the cervix, and metastatic renal carcinoma [18-20]. Several MetAP2 inhibitors were studied based on the inhibition of MetAP activity [21-27]. Previously, inhibition of MetAP2 by TNP470 has been shown to activate p53 for cell-cycle arrest $[25,26]$. In fact, the primary mouse embryonic fibroblasts were demonstrated to be sensitive to TNP470 and other MetAP2-specific inhibitors in a p53-dependent fashion $[25,26]$. In contrast, the majority of transformed tumor cells are largely resistant to TNP470, likely due to the pre-existing p53 mutations in them.

c-Src is frequently observed to be activated or overexpressed in a number of human cancers, especially those of colon and breast. Activation of c-Src is achieved upon its myristoylation for proper signal transduction. Since myristoylation reaction is catalyzed by NMT, we reported that a cross-talk among the MetAP2, NMT, and N-myristoyltransferase inhibitor protein 71 (NIP71) in HT29 cells [27]. Importantly, the Src family kinases have been shown to play pivotal roles in cell-cycle progression, making them potential candidates to mediate the cell-cycle effects of MetAP inhibitors. Western blot analysis revealed that phosphorylation of Src was significantly decreased by 1.0 $\mu \mathrm{M}$ of NC2213 (Figure 3B). We further investigated the molecular events associated with NC2213-induced cell cycle arrest by measuring the phosphorylation of Src, a myristoylated protein, is elevated in human colon cancer (Figure 3B). The phosphorylation of Src at Tyr417 and Tyr527 in HT29 cells was measured by Western blot analysis (Figure 3B). These observations lead us to the possi- 
A

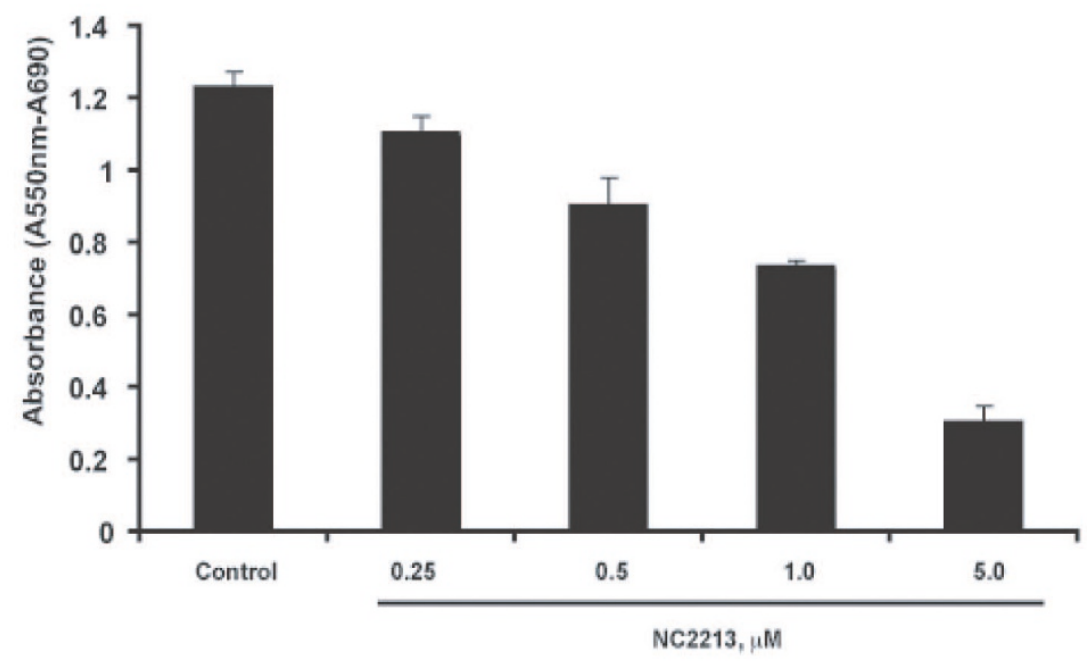

B
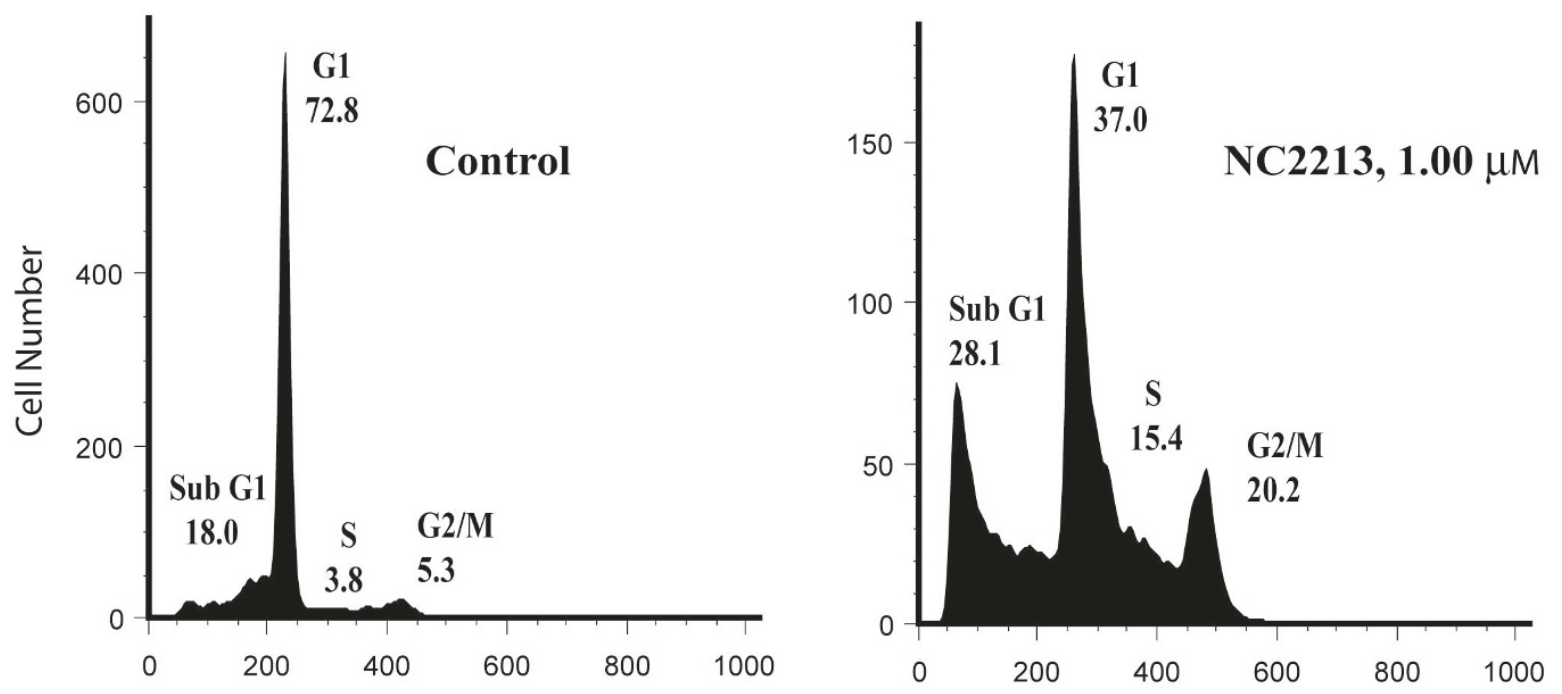

\section{DNA Content}

Figure 2

A, cell proliferation analysis of HT29 cells. The cells were treated with NC22 I 3 or DMSO (control) at various concentrations for 96 hours; B, cell cycle analysis of HT29 cells. The cells were treated with NC22 I 3 or DMSO (control) at various concentrations for 48 hours. Histograms represent the PI staining of DNA content in different phases of the cell cycle. Percentages of cells in each phase of the cell cycle are shown on the histograms. The data presented as the representative of at least three separate experiments. 
A

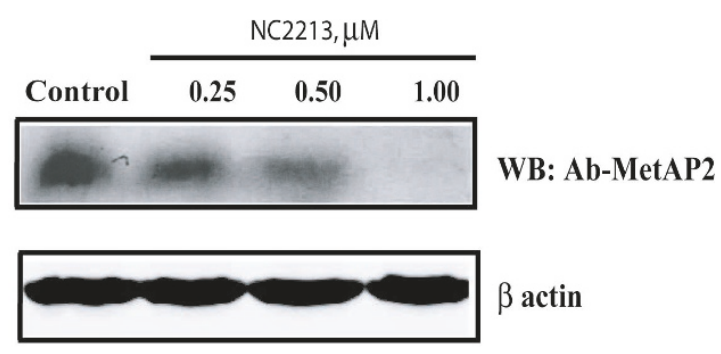

B

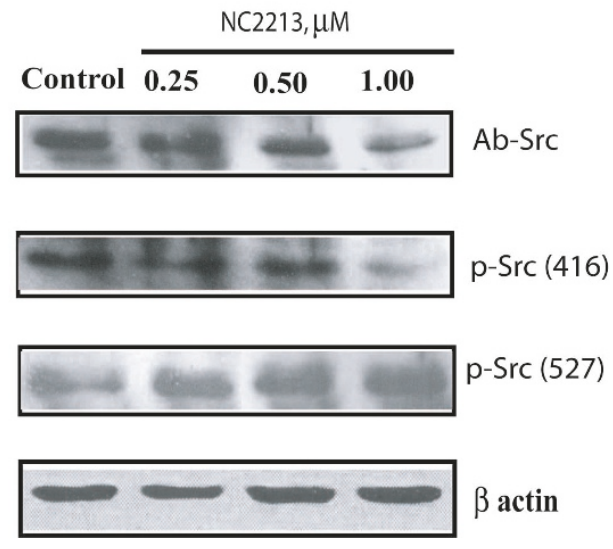

Figure 3

Expression of MetAP2 and Src in HT29 cells. A, expression of MetAP2; B, expression of Src. Cells were treated with NC22 I 3 at various concentrations for 48 hours. Equal amounts of proteins were loaded on to each lane, subjected to SDS-PAGE, transferred to nitrocellulose membrane, and blotted with anti-MetAP2, anti-pp60 ${ }^{\text {c-src }}$, antiphospho-Src (Tyr527), anti-phospho-Src (Tyr416), as described under Materials and Methods. $\beta$-Actin was used as a loading control. The data presented as the representative of at least three separate experiments.

bility of developing MetAP2 specific inhibitors, which may be therapeutically useful. In addition, it is important to study the regulation of MetAP2 and its involvement of various signal transduction pathways.

The possible role of MetAP2 and NMT in cell proliferation may be due to the interaction of these enzymes with various apoptotic factors. Increased expression of NMT in p53 mutant cases suggests that wild-type p53 may have a negative regulatory effect on NMT gene expression [28]. MetAP2 plays a critical role in the proliferation of endothelial cells and certain tumor cells and thus serves as a promising target for anti-angiogenesis and anticancer drugs [10]. It has been demonstrated that there is a high expression of MetAP2 in human mesothelioma tissue, and the association of this expression with anti-apoptotic function in those neoplastic cells [8]. In addition, the inhibition of MetAP2 expression in mesothelioma cells leads to cell death and that such apoptosis is avoided in cases where there is overexpression of $\mathrm{Bcl}-2$ [8]. The upregulation of $\mathrm{Bcl}-2$ in colorectal cancer is well established by various investigators [28-30]. One of the other mechanisms correlating with MetAP2 and apoptosis is through caspases [8]. A recent observation suggested that mesalazine-induced apoptosis in colon cancer cells is possible through activation of caspase-3 [31]. Chen et al reported a reduction in protein levels of caspase-3, caspase-7, and caspase- 9 in human colon cancer specimens [32].

In summary, we have identified a novel MetAP2 inhibitor NC2213, which is a structurally divergent to fumagillin, in HT29 cells. The MetAP2 expression was dose-dependently decreased when the HT29 cells were treated with NC2213. NC2213 also inhibits the expression of pp60 ${ }^{\mathrm{c}-\mathrm{src}}$ and the phosphorylation at Tyr417 while increasing the phosphorylation at Tyr527 of pp60 c-src in HT29 cells. Future detailed studies related to MetAP2 and apoptosis will shed light on the involvement of this enzyme in cell proliferation.

\section{Materials and methods Materials}

Anti-MetAP2 was purchased from Zymed Laboratories Inc., (USA). Anti-pp60c-src, anti-phospho-Src (Tyr527], and anti-phospho-Src (Tyr416] were purchased from Cell Signaling, USA. Cell culture media, anti- $\beta$-Actin and other reagents were from Invitrogen and Sigma. NC2213 was synthesized as described earlier (Figure 1) [13].

\section{Cell Culture and Cell Lysate Preparation}

The HT29 cells were grown as described elsewhere [27].

\section{Cell Proliferation Assay}

Cells were dissociated with $2.5 \mathrm{~g} / \mathrm{L}$ trypsin and resuspended in tissue culture media. Cells $\left(1 \times 10^{5}\right.$ cells $\left./ \mathrm{mL}\right)$ were added to 96-well plates (9000 cells/well) for $24 \mathrm{~h}$ at $37^{\circ} \mathrm{C}$. NC2213 was added at various concentrations ranging from $05 \mu \mathrm{M}$. After the cells were incubated with NC2213 for $96 \mathrm{~h}$, cell proliferation was estimated based on the cellular reduction of tetrazolium salt MTT by using a micro plate reader (BIO-RAD, Model 550 USA) at 540 $\mathrm{nm}$ [33].

\section{Cell Cycle Analysis}

Cell cycle analysis was carried out as described elsewhere [34]. Cells were treated with NC2213 at various concentrations ranging from $05 \mu \mathrm{M}$. After treatment for $48 \mathrm{~h}$, cells were trypsinized, washed in PBS, and fixed overnight in $70 \%$ ethanol at $4{ }^{\circ} \mathrm{C}$. At the time of harvest, the cultures were $7090 \%$ confluent. The ethanol solution was subsequently removed after centrifugation, and cells were resus- 
pended in a buffer containing $10 \mathrm{mM}$ Tris (pH 7.5), 125 $\mathrm{mM}$ sucrose, $2.5 \mathrm{mM} \mathrm{MgCl} 2,0.185 \% \mathrm{NP} 40,0.02 \mathrm{mg} / \mathrm{ml}$ RNase A, 0.05\% sodium citrate, and $25 \mu \mathrm{g} / \mathrm{ml}$ PI. After incubation on ice for $1 \mathrm{~h}$, cells were subjected to DNA content analysis using a FACScan cytometer (Becton Dickinson).

\section{SDS-Polyacrylamide Gel Electrophoresis and Western Blot Analysis}

SDS-PAGE prepared according to the procedure described by Laemmli[35]. Gel transfer to nitrocellulose membrane and blocking were performed using standard procedures [36]. The blot was incubated with the primary antibodies at 1:1000, washed and probed with an anti-rabbit or antimouse IgG horseradish peroxidase conjugate diluted $1: 2000$.

\section{Other Methods}

Protein concentration was measured by the method of Bradford [37] using bovine serum albumin as a standard.

\section{Abbreviations}

MetAP2: Methionine aminopeptidase; NMT: N-myristoyltransferase; TNP470: O-(chloro-acetyl-carbamoyl) fumagillol; NIP71: N-myristoyltransferase inhibitor protein 71 ;

\section{Competing interests}

The authors declare that they have no competing interests.

\section{Authors' contributions}

PS and RKS conceived, and planned the experiments. AL did flow cytometry analysis. UD, HNP and JRD provided the NC2213 compound. All authors read and approved the manuscript.

\section{Acknowledgements}

This work is supported by the Canadian Institutes of Health Research, Canada [RKS and JRD].

\section{References}

I. Jackson R, Hunter T: Role of methionine in the initiation of haemoglobin synthesis. Nature 1970, 227:672-676.

2. Solbiati J, Chapman-Smith A, Miller JL, Miller CG, Cronan JE Jr: Processing of the $\mathbf{N}$ termini of nascent polypeptide chains requires deformylation prior to methionine removal. J Mol Biol 1999, 290:607-614.

3. Selvakumar P, Lakshmikuttyamma A, Dimmock JR, Sharma RK: Methionine aminopeptidase 2 and cancer. Biochim Biophys Acto 2006, I 765: | $48-154$.

4. Selvakumar P, Lakshmikuttyamma A, Shrivastav A, Das SB, Dimmock JR, Sharma RK: Potential role of $\mathbf{N}$-myristoyltransferase in cancer. Prog Lipid Res 2007, 46: I-36.

5. Datta $R$, Choudhury P, Ghosh A, Datta B: A glycosylation site, 60SGTS63, of p67 is required for its ability to regulate the phosphorylation and activity of eukaryotic initiation factor 2 alpha. Biochemistry 2003, 42:5453-5460.

6. Datta B, Datta R: Induction of apoptosis due to lowering the level of eukaryotic initiation factor 2 -associated protein, p67 from mammalian cells by antisense approach. Exp Cell Res 1999, 246:376-383.
7. Sheen IS, Jeng KS, Jeng WJ, Jeng CJ, Wang YC, Gu SL, Tseng SY, Chu $\mathrm{CM}$, Lin CH, Chang KM: Fumagillin treatment of hepatocellular carcinoma in rats: an in vivo study of antiangiogenesis. World J Gastroenterol 2005, I I:77| -777.

8. Catalano A, Romano M, Robuffo I, Strizzi L, Procopio A: Methionine aminopeptidase- 2 regulates human mesothelioma cell survival: role of $\mathrm{Bcl}-2$ expression and telomerase activity. $\mathrm{Am} J$ Pathol 200I, I 59:72I-73I.

9. Kanno T, Endo H, Takeuchi K, Morishita Y, Fukayama M, Mori S High expression of methionine aminopeptidase type 2 in germinal center $B$ cells and their neoplastic counterparts. Lab Invest 2002, 82:893-901.

10. Bo H, Ghazizadeh M, Shimizu H, Kurihara Y, Egawa S, Moriyama Y, Tajiri T, Kawanami O: Effect of ionizing irradiation on human esophageal cancer cell lines by cDNA microarray gene expression analysis. J Nippon Med Sch 2004, 7 I: I 72- I80.

II. Morowitz MJ, Barr R, Wang Q, King R, Rhodin N, Pawel B, Zhao H, Erickson SA, Sheppard GS, Wang J, Maris JM, Shusterman S: Methionine aminopeptidase 2 inhibition is an effective treatment strategy for neuroblastoma in preclinical models. Clin Cancer Res 2005, I I:2680-2685.

12. Selvakumar P, Lakshmikuttyamma A, Kanthan R, Kanthan SC, Dimmock JR, Sharma RK: High expression of methionine aminopeptidase $\mathbf{2}$ in human colorectal adenocarcinomas. Clin Cancer Res 2004, 10:2771-2775.

13. Pati HN, Das U, Quail JW, Kawase M, Sakagami H, Dimmock JR: Cytotoxic 3,5-bis(benzylidene)piperidin-4-ones and $\mathbf{N}$-acyl analogs displaying selective toxicity for malignant cells. Eur Med Chem 2008, 43:1-7.

14. Tucker LA, Zhang Q, Sheppard GS, Lou P, Jiang F, McKeegan E, Lesniewski R, Davidsen SK, Bell RL, Wang J: Ectopic expression of methionine aminopeptidase- 2 causes cell transformation and stimulates proliferation. Oncogene 2008, 27:3967-3976.

15. Abe J, Zhou W, Takuwa N, Taguchi J, Kurokawa K, Kumada M, Takuwa $Y$ : A fumagillin derivative angiogenesis inhibitor, AGM-inhibits activation of cyclin-dependent kinases and phosphorylation of retinoblastoma gene product but not protein tyrosyl phosphorylation or protooncogene expression in vascular endothelial cells. Cancer Res 1470 , 54:3407-3412.

16. Adams BK, Ferstl EM, Davis MC, Herold M, Kurtkaya S, Camalier RF, Hollingshead MG, Kaur G, Sausville EA, Rickles FR, Snyder JP, Liotta DC, Shoji M: Synthesis and biological evaluation of novel curcumin analogs as anti-cancer and anti-angiogenesis agents. Bioorg Med Chem 2004, 1 2:3871-3883.

17. Hu X, Dang Y, Tenney K, Crews P, Tsai CW, Sixt KM, Cole PA, Liu J: Regulation of c-Src nonreceptor tyrosine kinase activity by bengamide $A$ through inhibition of methionine aminopeptidases. Chem Biol 2007, I 4:764-774.

18. Dezube BJ, Von Roenn JH, Holden-Wiltse J, Cheung TW, Remick SC, Cooley TP, Moore J, Sommadossi JP, Shriver SL, Suckow CW, Gill PS: Fumagillin analog in the treatment of Kaposi's sarcoma: a phase I AIDS Clinical Trial Group study. J Clin Oncol 1998 16:1444-1449.

19. Kruger EA, Figg WD: TNP-470: an angiogenesis inhibitor in clinical development for cancer. Expert Opin Investig Drugs 2000 , 9:1383-I396.

20. Kudelka AP, Levy T, Verschraegen CF, Edwards CL, Piamsomboon S, Termrungruanglert W, Freedman RS, Kaplan AL, Kieback DG, Meyers CA, Jaeckle KA, Loyer E, Steger M, Mante R, Mavligit G, Killian A, Tang RA, Gutterman JU, Kavanagh J]: A phase I study of TNP-470 administered to patients with advanced squamous cell cancer of the cervix. Clin Cancer Res 1997, 3:I50I-I505.

21. Griffith EC, Su Z, Niwayama S, Ramsay CA, Chang YH, Liu JO Molecular recognition of angiogenesis inhibitors fumagillin and ovalicin by methionine aminopeptidase 2. Proc Natl Acad Sci USA 1998, 95:15183-15188.

22. Antoine N, Greimers R, De Roanne C, Kusaka M, Heinen E, Simar LJ, Castronovo V: AGM a potent angiogenesis inhibitor, prevents the entry of normal but not transformed endothelial cells into the GI phase of the cell cycle. Cancer Res I470, 54:2073-2076.

23. Kusaka M, Sudo K, Matsutani E, Kozai Y, Marui S, Fujita T, Ingber D, Folkman J: Cytostatic inhibition of endothelial cell growth by the angiogenesis inhibitor TNP-470 [AGM-1470]. Br J Cancer $1994,69: 212-216$. 
24. Wang J, Lou P, Henkin J: Selective inhibition of endothelial cell proliferation by fumagillin is not due to differential expression of methionine aminopeptidases. J Cell Biochem 2000, 77:465-473.

25. Yeh JR, Mohan R, Crews CM: The antiangiogenic agent TNP470 requires $\mathrm{p} 53$ and $\mathrm{p} 2 \mathrm{ICIP} / \mathrm{WAF}$ for endothelial cell growth arrest. Proc Natl Acad Sci USA 2000, 97:12782-1 2787.

26. Zhang Y, Griffith EC, Sage J, Jacks T, Liu JO: Cell cycle inhibition by the anti-angiogenic agent TNP-470 is mediated by p53 and p2 I WAFI/CIPI. Proc Natl Acad Sci USA 2000, 97:6427-6432.

27. Selvakumar P, Lakshmikuttyamma A, Lawman Z, Bonham K, Dimmock JR, Sharma RK: Expression of methionine aminopeptidase 2, N-myristoyltransferase, and $\mathbf{N}$-myristoyltransferase inhibitor protein 71 in HT29. Biochem Biophys Res Commun 2004, 322: $1012-1017$.

28. Rajala RV, Radhi JM, Kakkar R, Datla RS, Sharma RK: Increased expression of $\mathbf{N}$-myristoyltransferase in gallbladder carcinomas. Cancer 2000, 88:1992-1999.

29. Yu HG, Yu LL, Yang Y, Luo HS, Yu JP, Meier JJ, Schrader H, Bastian A, Schmidt WE, Schmitz F: Increased expression of RelA/nuclear factor-kappa B protein correlates with colorectal tumorigenesis. Oncology 2003, 65:37-45.

30. Valassiadou KE, Stefanaki K, Tzardi M, Datseris G, Georgoulias V, Melissas J, Tsiftsis DD, Delides G, Kanavaros P: Immunohistochemical expression of $\mathrm{p} 53, \mathrm{bcl}-2, \mathrm{mdm} 2$ and waf $1 / \mathrm{p} 2 \mathrm{I}$ proteins in colorectal adenocarcinomas. Anticancer Res 1997, I 7:257|-2576.

31. Reinacher-Schick A, Schoeneck A, Graeven U, Schwarte-Waldhoff I, Schmiegel W: Mesalazine causes a mitotic arrest and induces caspase-dependent apoptosis in colon carcinoma cells. Carcinogenesis 2003, 24:443-45I.

32. Chen T, Yang I, Irby R, Shain KH, Wang HG, Quackenbush J, Coppola $D$, Cheng JQ, Yeatman TJ: Regulation of caspase expression and apoptosis by adenomatous polyposis coli. Cancer Res 2003, 63:4368-4374.

33. Carmichael J, DeGraff WG, Gazdar AF, Minna JD, Mitchell JB: Evaluation of a tetrazolium-based semiautomated colorimetric assay: assessment of chemosensitivity testing. Cancer Res 1987, 47:936-942.

34. Lakshmikuttyamma A, Pastural E, Takahashi N, Sawada K, Sheridan DP, DeCoteau JF, Geyer CR: Bcr-Abl induces autocrine IGF-I signaling. Oncogene 2008, 27:383I-3844.

35. Laemmli UK: Cleavage of structural proteins during the assembly of the head of bacteriophage T4. Nature 1970, 227:680-685.

36. Towbin H, Staehelin T, Gordon J: Electrophoretic transfer of proteins from polyacrylamide gels to nitrocellulose sheets: procedure and some applications. Proc Natl Acad Sci USA 1979, 76:4350-4354

37. Bradford MM: A rapid and sensitive method for the quantitation of microgram quantities of protein utilizing the principle of protein-dye binding. Anal Biochem 1976, 72:248-254.

Publish with Bio Med Central and every scientist can read your work free of charge

"BioMed Central will be the most significant development for disseminating the results of biomedical research in our lifetime. "

Sir Paul Nurse, Cancer Research UK

Your research papers will be:

- available free of charge to the entire biomedical community

- peer reviewed and published immediately upon acceptance

- cited in PubMed and archived on PubMed Central

- yours - you keep the copyright
BioMedcentral 